\title{
PECULIARITIES OF USE OF THE COMPOSITIONS BASED ON BIOTECHNOLOGY PRODUCTS FOR ROOTING OF THUJA CUTTINGS
}

\author{
V. Shvets, O. Karpenko
}

Department of Physical Chemistry of Fossil Fuels InPOCC, National Academy

of Sciences of Ukraine

V. Novikov, V. Lubenets

Lviv Polytechnic National University

\begin{tabular}{l} 
Key words: \\
Thuya occidentalis $L$. \\
Alylthiosulfanilate \\
Etilthiosulfanilate \\
Rhamolipid biocomplex \\
Trehalose lipid \\
Surfactants \\
compositions \\
Stubby cuttings rooting \\
\hline
\end{tabular}

Article history:

Received 03.09.2018

Received in revised form

27.09.2018

Accepted 15.10.2018

Corresponding author:

V. Shvets

E-mail:

npnuht@ukr.net

\begin{abstract}
The effectiveness of the compositions based on thiosulfonates and environmentally safe surface-active rhamnolipid biocomplex (at various ratios) on rooting of stubby cuttings of Thuja occidentalis L. have been established. Thuja is one of the most important plant in modern ornamental horticulture.

The starting material for the reproduction of Thuja occidentalis L. was stubby cuttings of the uterine brood plants of the age of about 20 years. The harvested stubby cuttings of thuja (10-15 cm long) were soaked in prepared solutions of the biosurfactants, biocides and their compositions during 12 hours. The using preparations: rhamonolipid biocomplex the biosynthesis product of the strain Pseudomonas sp. PS17, trehalose lipid surfactants of the strain Rhodococcus etrythropolis $\mathrm{Au}-1$, biocides-thiosulfonates: allylthiosulphanylate and ethilthiosulfanilate, as well as compositions based on them in ratios $1: 1$ and $2: 1$ and the commercial phytohormone for rooting promotion - indolyl-3-acetic acid).

It was found that the best result of Thuja occidentalis L. rooting was obtained when the composition alitythiosulfanilate and rhamonolipid biocomplex in the ratio $1: 1$ were used: the rooting efficiency of cuttings of planting material has been increased by $50 \%$ compared to the control. The obtained results indicate the prospects of using the created compositions based on the thiosulfonates and the biogenic surfactants as rooting stimulators in environmentally safe technologies for modern ornamental horticulture.
\end{abstract}

DOI: $10.24263 / 2225-2924-2018-24-5-5$ 


\title{
ОСОБЛИВОСТІ ВИКОРИСТАННЯ КОМПОЗИЦІЙ НА ОСНОВІ ПРОДУКТІВ БІОТЕХНОЛОГІЇ ДЛЯ УКОРІНЕННЯ ЖИВЦІВ ТУЇ ЗАХІДНОї
}

\author{
В.В. Швець, О.В. Карпенко \\ Відділення фізико-хімії горючих копалин ІнФОВ ім. Л.М. Литвиненка \\ НАН України
}

\author{
В.І. Лубенець, В.П. Новіков \\ Національний університет «Львівська політехніка»
}

У статті доведено ефективність композииій на основі біоцидів-тіосульфонатів і екологічно безпечного поверхнево-активного рамноліпідного біокомплексу (за різних співвідношень) при укоріненні здерев'янілих живців туі західної (Thuja occidentalis L.) — однієї з важливих у вітчизняному декоративному садівництві рослин.

Вихідним матеріалом для розмноження туї західної (Thuja occidentalis L.) були стеблові здерев'янілі живиі маточних рослин туї західної, вік яких близько 20 років. Заготовлені задерев'янілі живиі туї довжиною 10-15 см на 12 годин занурювали у підготовлені дослідні розчини: рамноліпідного біокомплексу - продукту біосинтезу штаму Pseudomonas sp. PS-17, трегалозоліпідних поверхнево-активних речовин штаму Rhodococcus erythropolis AU-1 біоцидів-тіосульфонатів алілтіосульфанілату $i$ етилтіосульфанілату та композииій на їх основі у співвідношеннях 1:1 і 2:1. Для порівняння використовували комериійний фітогормон для коренеутворення - індоліл-3-оцтову кислоту.

Встановлено, щзо найкращий результат укорінення туї західної отримано за використання композичії алілтіосульфанілату та біоПАР у співвідношенні 1:1. Це дало змогу підвищити ефективність укорінення живиів садивного матеріалу Thuja occidentalis L. на 50\% порівняно з контролем. Одержані результати вказують на перспективність використання композищій на основі біоцидів-тіосульфонатів $i$ біогенних ПАР як стимуляторів коренеутворення в екологічно безпечних технологіях для сучасного декоративного садівництва.

Ключові слова: туя західна (Thuја осcidentalis L.), алілтіосульфанілат, етилтіосульфанілат, рамноліпідний біокомплекс, трегалозоліпіди, здерев'янілий живець, живиювання.

Постановка проблеми. В наш час для задоволення зростаючих потреб у посадковому матеріалі декоративних культур, до яких належить Thuja occidentalis L., постає питання розроблення технологій укорінення саджанців цих рослин [1]. У зв'язку із значним збільшенням обсягів вирощування садивного матеріалу у вітчизняному декоративному розсадництві суттєво зросла потреба в ефективних біологічно активних речовинах для стимулювання коренеутворення живців. Натепер посадковий матеріал туї, доступний покупцеві, в 
основному має закордонне походження, в Україні здійснюється лише дорощування, що й зумовлює його високу ціну [2]. Основними перешкодами на шляху до промислового виробництва садивного матеріалу туї $є$ потреба у дорогих стимуляторах коренеутворення та теплицях із туманоутворючою установкою, в яких можна буде регулювати вологість і температуру повітря [3].

Як показує досвід зарубіжних і провідних вітчизняних розсадників, використання синтетичних і природних регуляторів росту 3 фітогормональною активністю не тільки стимулює укорінення живців, а й сприяє збільшенню виходу кореневласних саджанців, підвищенню якості вихідного садивного матеріалу та зменшенню його технологічної собівартості [4].

Тому нині є нагальна необхідність створення композицій нового покоління - зручних для застосування, які можуть знижувати дію несприятливих факторів довкілля, а також зводити до мінімуму негативну дію грунтових фітопатогенів і таким чином стимулювати укорінення. Водночас вони мають бути нешкідливими для навколишнього середовища.

3 попередніх досліджень відома рістрегулююча дія й антимікробна активність тіосульфонатів, які $\epsilon$ структурними аналогами біоциду аліцину активної антимікробної речовини часнику і цибулі [5]. Проте ці сполуки характеризуються низькою розчинністю у воді, що ускладнює їх використання як потенційних препаратів. Цю проблему можна вирішити шляхом розроблення композицій тіосульфонатів з біогенними поверхнево-активними речовинами (біоПАР), що сприяють їх солюбілізації, підвищенню ефективності та зменшенню робочих концентрацій біоцидів, що важливо з економічної й екологічної точки зору. Доцільність використання біоПАР зумовлена їх особливими властивостями (поверхнева й емульгувальна активність, змочування поверхонь, вплив на проникність клітинних мембран), що визначає їх перспективи для створення комплексних препаратів 3 різними біологічно активними речовинами, у тому числі слаборозчинними тіосульфонатами [6].

Метою статті $\epsilon$ дослідження процесу укорінення живців туї західної 3 використанням композицій алілтіосульфанілату й етилтіосульфанілату 3 біоПАР (рамноліпідним біокомплексом і трегалозоліпідними ПАР), підбір їх оптимальних співвідношень, а також доцільності їх застосування в агротехнологіях вирощування туї західної Thuja occidentalis L.

Матеріали і методи. Дослідження особливостей укорінення живців туї західної (Thuja occidentalis L.) проводили у Відділі фізико-хімії горючих копалин ІнФОВ ім. Л.М. Литвиненка Національної академії наук України за вегетаційний період (2017-2018рp.).

Вихідним матеріалом для розмноження Thuja occidentalis L. були стеблові здерев'янілі живці, заготівля живцевого матеріалу проводилась вранці [7]. Для живцювання використовували маточні рослини T. occidentalis L. віком близько 20 років. Заготовлені задерев'янілі живці туї довжиною $10-15$ см (рис. 1) на 12 годин занурювали у підготовлені розчини: рамноліпідного біокомплексу (РБК), 0,01 г/дм - продукту біосинтезу штаму Pseudomonas sp. PS-17, трегалозоліпідних ПАР штаму Rhodococcus erythropolis AU-1 (ТЛ), 0,05 г/дм³ , отримані у Відділенні фізико-хімії горючих копалин ІнФОВ та 
біоцидів-тіосульфонатів: алілтіосульфанілату (АТС) і етилтіосульфанілату (ЕTC), 0,01 г/дм ${ }^{3}$, синтезованих у НУ «Львівська політехніка», а також композицій на їх основі у співвідношеннях 1:1 і 2:1, 0,01 г/дм³ відповідно. Для порівняння використовували розчин індоліл-3-оцтової кислоти (ІОК), 0,02 г/дм³.

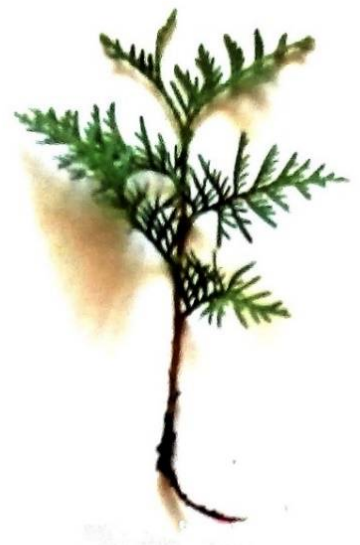

Рис. 1. Живець T. occidentalis L., підготовлений для досліджень

Живці висаджували у ящики розміром $0,5 \times 0,2 \times 0,15$ м, які були заповнені попередньо зволоженим універсальним торф'яним субстратом на глибину $1,5-3$ см, відстань між живцями становила: в рядах - $3-5$ см; між рядками 5-7 см. На кожний варіант було заготовлено 10 шт. здерев' янілих живців. Протягом періоду укорінення підтримували оптимальну вологість близько $80 \%$. Аналіз живців проводили 3 урахуванням їхнього стану [8] за такими категоріями: 1 - здорові з приростом; 2 - ослаблені; 3 - сильно ослаблені (з ознаками всихання, всохло до половини висоти живця); $4-$ всихаючі (всохло більше половини висоти живця); 5 - сухі. Індекс стану $\left(I_{c}\right)$ загалом у досліді визначали за формулою (1):

$$
I_{c}=\frac{K_{1} \cdot n_{1}+K_{2} \cdot n_{2}+\ldots+K_{5} \cdot n_{5}}{N},
$$

де: $I_{c}-$ індекс стану живців у досліді; $K_{l}, \ldots, K_{5}$ - категорія живця (від 1 до 5); $n_{1}, \ldots, n_{5}$ - кількість живців за зазначеними категоріями; $N-$ загальна кількість врахованих у досліді живців.

Наближення числового значення індексу стану живців до 1 свідчить про покращення їх санітарного стану, i, навпаки, зростання чисельного значення $I_{c}$ показує погіршення стану живців. Коли $I_{c}$ дорівнює 5 , це свідчить про суцільне всихання рослин.

Результати і обговорення. За результатами проведених досліджень, замочування живців туї західної у розчини досліджених препаратів і композицій на основі біоПАР (РБК, ТЛ) та біоцидів тіосульфонатів (АТС, ЕТС) мало позитивний вплив на укорінення (табл. 1). 
Таблиця 1. Вплив продуктів біотехнології на процес укорінення здерев'янілих живців Thuja occidentalis L.

\begin{tabular}{|c|c|c|c|c|c|c|c|c|c|c|}
\hline $\begin{array}{l}\text { 藏 } \\
\text { 貝 } \\
\text { 年 }\end{array}$ & 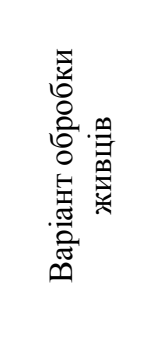 & 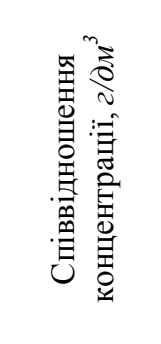 & 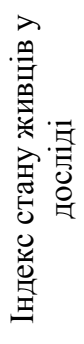 & 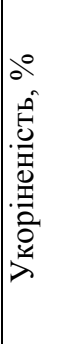 & $\begin{array}{l}\text { o̊ } \\
\overrightarrow{\hat{o}} \\
\stackrel{0}{0} \\
\text { m }\end{array}$ & 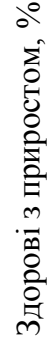 & 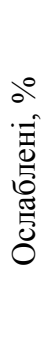 & 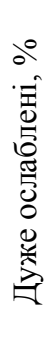 & 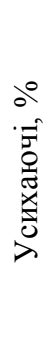 & $0^{0}$ \\
\hline 1 & Контроль & - & 2,3 & 40 & 40 & - & 20 & 10 & 15 & 15 \\
\hline 2 & IOK & 0,02 & 1,9 & 70 & 40 & 30 & 10 & 10 & - & 10 \\
\hline 3 & РБК & 0,01 & 2,2 & 50 & 50 & - & 20 & 5 & 10 & 15 \\
\hline 4 & ТЛ & 0,05 & 2,5 & 50 & 50 & - & 20 & 10 & - & 20 \\
\hline 5 & ATC & 0,01 & 3,9 & 20 & 20 & - & - & 30 & - & 50 \\
\hline 6 & ETC & 0,01 & 2,7 & 50 & 50 & - & 10 & 10 & - & 30 \\
\hline 7 & РБК+ATC & $0,01: 0,01$ & 1,4 & 90 & 50 & 40 & - & - & 5 & 5 \\
\hline 8 & РБК+ETC & $0,01: 0,01$ & 2,8 & 60 & 50 & 10 & - & - & - & 40 \\
\hline 9 & ТЛ+AТC & $0,01: 0,01$ & 2,9 & 50 & 50 & - & - & - & 10 & 40 \\
\hline 10 & ТЛ+ETC & $0,01: 0,01$ & 3,7 & 20 & 20 & - & 10 & - & 30 & 40 \\
\hline 11 & РБК+ATC & $0,01: 0,005$ & 1,8 & 80 & 60 & 20 & - & - & - & 20 \\
\hline 12 & РБК+ETC & $0,01: 0,005$ & 3,1 & 40 & 40 & - & 10 & 10 & - & 40 \\
\hline 13 & ТЛ+AТС & $0,01: 0,005$ & 2,9 & 50 & 50 & - & - & - & 10 & 40 \\
\hline 14 & ТЛ+ ETC & $0,01: 0,005$ & 3,8 & 20 & 30 & - & - & - & 10 & 60 \\
\hline
\end{tabular}

Примітка: контроль - дистильована вода; IOК - індоліл-3-оцтова кислота; РБК рамноліпідний біокомплекс; ТЛ - трегалозоліпідні ПАР; АТС — алілтіосульфанілат; ЕТС - етилтіосульфанілат.

Укоріненість живців визначено як суму здорових рослин (табл. 1). Цей

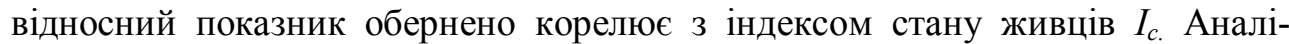
зуючи дані табл. 1, необхідно зазначити, що у варіантах, які були оброблені препаратом IOK та композиціями РБК+АТC у співвідношеннях 1:1 і 2:1, отримано кращі розраховані показники $I_{c}$ порівняно 3 контролем. Проте у варіанті РБК+АТС (2:1), всохлих рослин було більше у 4 рази, ніж при співвідношенні 1:1. У переважній більшості варіантів, де використовували композиції трегалозоліпідів 3 тіосульфонатами (ТЛ+АТС і ТЛ+ЕТС) за співвідношень 1:1 і 2:1, показник індексу стану живців був вищим порівняно 3 контролем, за винятком досліду з ТЛ.

Як видно 3 рис. 1, довжина кореневої системи та приріст біомаси у варіанті з ІОК становила $0,73 \mathrm{~cm}$ і $0,8 \mathrm{~cm}$, тоді як у контролі цей показник мав величину 0,52 см і 0,4 см відповідно. Максимальне значення довжини кореневої системи 0,83 см та приріст біомаси на 1,2 см відмічено у варіанті, де використовували композицію РБК+АТС (1:1). У цьому варіанті на живцях утворилися корені на $60 \%$ довші, ніж у контрольному варіанті, а приріст біомаси був на $45 \%$ більшим. 


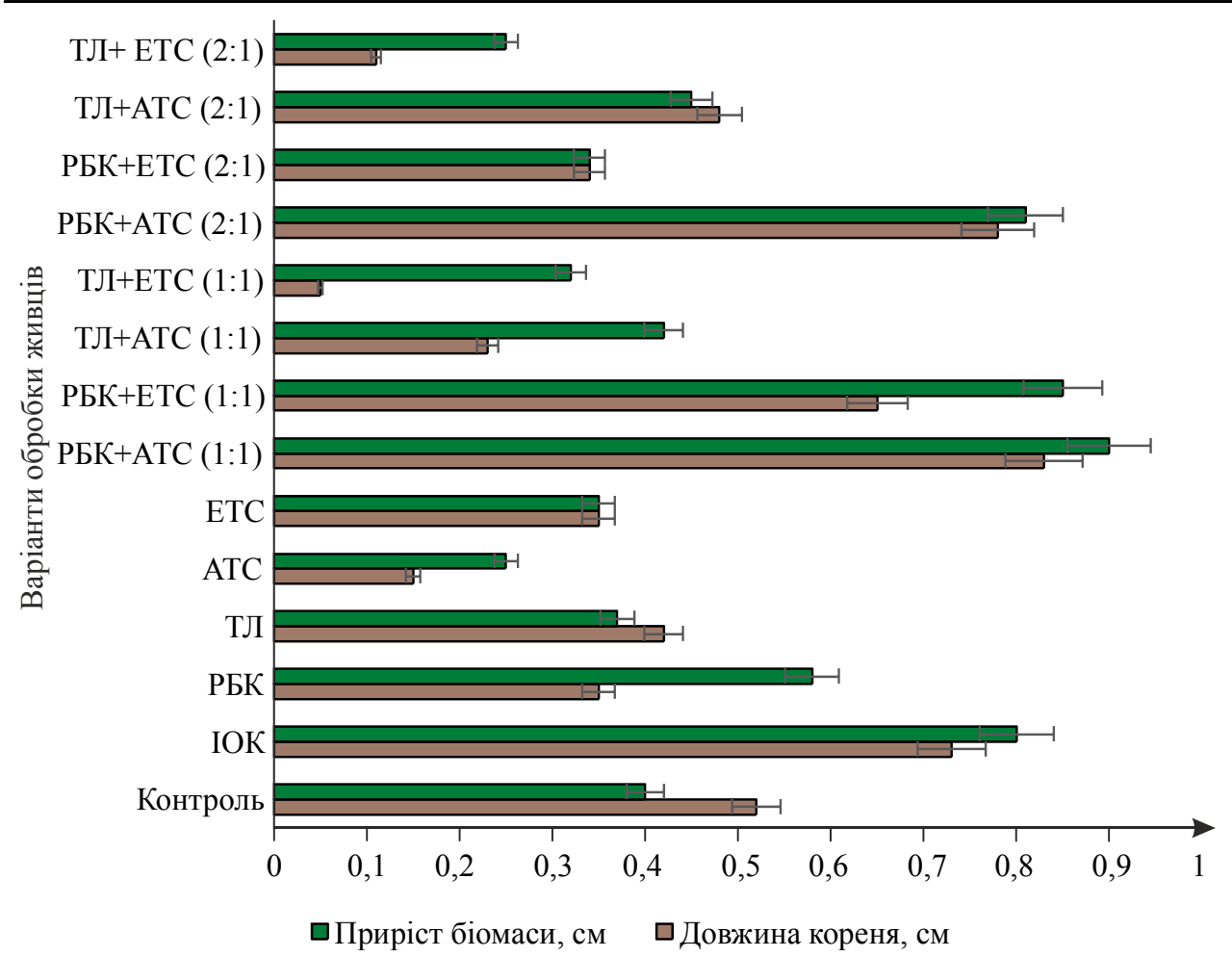

Рис. 1. Довжина кореня та приросту біомаси живців туї західної під впливом стимуляторів коренеутворення: контроль - дистильована вода; IOK - 3-індоліл-3оцтова кислота; РБК - рамноліпідний біокомплекс; ТЛ — трегалозоліпіди;

АТC — алілтіосульфанілат; ЕТС — етилтіосульфанілат; показники дослідних варіантів імовірно відмінні від контролю, $\mathrm{P} \geq 0,05$

Результати свідчать, що застосування досліджених речовин стимулює ріст i розвиток стеблових здерев'янілих живців Thuja occidentalis. Застосування IOK та створеної композиції РБК+АТС (1:1) стимулювало не тільки укорінення, але й розміри надземної частини живців.

\section{Висновки}

Отримані результати вегетативного розмноження живцюванням декоративних форм туї західної Thuja occidentalis L. свідчать, що використання стимуляторів РБК+АТС (1:1) та РБК+АТС (2:1) для оброблення здерев'янілих живців забезпечує найвищу ефективність їх укорінення, що перевершує дію традиційного синтетичного стимулятора укорінення - індоліл-3-оцтової кислоти. При цьому найбільше укорінених зелених живців отримано при застосуванні розробленої композиції РБК+АТС у співвідношенні 1:1, при оброблені якою укорінення живців становило 90\%.

\section{Література}

1. Коваль С.А. Утворення додаткових коренів у стеблових живців туї західної (форма колоноподібна) залежно від оброблення росторегулятивною речовиною. Науковий вісник НЛТУ Украӥни. 2014. № 24. С. 85-91. 
2. Токмань В.С., Кириченко Я.С. Особливості вегетативного розмноження Thuja occidentalis L. в умовах Сумського НАУ. Вісник Сумського національного аграрного універсиmету. Науковий журнал Серія «Агрономія і біологія». Суми. 2015. Випуск 3(27). С. 78 - 81.

3. Маргітай Л.Г. Вплив регуляторів росту на вкорінення живців Thuja occidentalis L. Науковий вісник Ужсгородського університету Серія Біологія. Випуск 27. 2010. С. 121-124.

4. Балабушка В.К., Маринич I.С., Бабицький А.І. Вегетативне розмноження малопоширених листопадних і хвойних деревних та чагарникових рослин здерев'янілими (зимовими) живцями у відкритому грунті. Агробіологія. 2012. № 8. C. 23-27. URL: http://nbuv.gov.ua/UJRN/agr_2012_8_8.

5. Synthesis and antimicrobial properties of 4-acylaminobenzenethiosulfoacid S-esters / Lubenets V., Vasylyuk S., Monka, N., Bolibrukh K., Komarovska-Porokhnyavets O., Baranovych D., Musyanovych R., Zaczynska E., Czarny A., Nawrot U., Novikov V. Saudi Pharmaceutical Journal. April 13, 2016. P. 266-274.

6. Антимікробна активність композицій на основі тіосульфонатів і біогенних поверхнево-активних речовин щодо фітопатогенів / В.В. Швець, О.В. Карпенко, І.В. Карпенко, В.І. Лубенець, В.П. Новіков. Наукові вісті НТУУ «КПІ». 2017. 3. С. $89-94$.

7. Маурер B.М., Кушнір А.І. Методичні рекомендації з розмноження деревних декоративних рослин Ботанічного саду НУБіП України. Київ: Вид-во НУБіП України, 2008. С. 55.

8. Використання «Рокогуміну» для живцювання хвойних порід у декоративному розсаднику ДП «Тростянецьке ЛГ» / В.А. Ігнатенко, А.В. Сотнікова, П.Б. Тарнопільський, Г.Б. Гладун, О.М. Даниленко, П.О. Волков. Харків: УкрНДІЛГА, 2016. Вип. 129. С. 100-107. 